\title{
Synthesis, Characterization, and BSA-Binding Studies of Novel Sulfonated Zinc-Triazine Complexes
}

\author{
Nalin Abeydeera, ${ }^{1}$ Inoka C. Perera, ${ }^{2}$ and Theshini Perera $\mathbb{D}^{1}$ \\ ${ }^{1}$ Department of Chemistry, University of Sri Jayewardenepura, Nugegoda, Sri Lanka \\ ${ }^{2}$ Department of Zoology and Environmental Science, University of Colombo, Colombo, Sri Lanka
}

Correspondence should be addressed to Theshini Perera; theshi@sjp.ac.lk

Received 18 August 2017; Revised 9 November 2017; Accepted 28 November 2017; Published 18 February 2018

Academic Editor: Francesco Paolo Fanizzi

Copyright ( $) 2018$ Nalin Abeydeera et al. This is an open access article distributed under the Creative Commons Attribution License, which permits unrestricted use, distribution, and reproduction in any medium, provided the original work is properly cited.

\begin{abstract}
Four $\mathrm{Zn}(\mathrm{II})$ complexes containing a pyridyl triazine core ( $L 1=3$-(2-pyridyl)-5,6-di(2-furyl)-1,2,4-triazine- $5^{\prime}, 5^{\prime \prime}$-disulfonic acid disodium salt and $L 2=3$-(2-pyridyl)-5,6-diphenyl-1,2,4-triazine- $4^{\prime}, 4^{\prime \prime}$-disulfonic acid sodium salt) were synthesized, and their chemical formulas were finalized as $\left[\mathrm{Zn}(\mathrm{L} 1) \mathrm{Cl}_{2}\right] \cdot 5 \mathrm{H}_{2} \mathrm{O} \cdot \mathrm{ZnCl}_{2}(\mathbf{1}),\left[\mathrm{Zn}(\mathrm{L} 1)_{2} \mathrm{Cl}_{2}\right] \cdot 4 \mathrm{H}_{2} \mathrm{O} \cdot 2 \mathrm{CH}_{3} \mathrm{OH}(2),\left[\mathrm{Zn}\left(\mathrm{L}_{2}\right) \mathrm{Cl}_{2}\right] \cdot 3 \mathrm{H}_{2} \mathrm{O} \cdot \mathrm{CH}_{3} \mathrm{OH}$ (3), and $\left[\mathrm{Zn}(\mathrm{L} 2)_{2} \mathrm{Cl}_{2}\right](4)$. The synthesized complexes are water soluble, making them good candidates for biological applications. All four complexes have been characterized by elemental analysis and ${ }^{1} \mathrm{H}$ NMR, IR, and UV-Vis spectroscopy. The IR stretching frequency of $\mathrm{N}=\mathrm{N}$ and $\mathrm{C}=\mathrm{N}$ bonds of complexes 1-4 have shifted to lower frequencies in comparison with free ligands, and a bathochromic shift was observed in UV-Vis spectra of all four complexes. The binding studies of ligands and complexes 1-4 with bovine serum albumin (BSA) resulted binding constants $\left(K_{\mathrm{b}}\right)$ of $3.09 \times 10^{4} \mathrm{M}^{-1}, 12.30 \times 10^{4} \mathrm{M}^{-1}$, and $16.84 \times 10^{4} \mathrm{M}^{-1}$ for ferene, complex 1, and complex 2 , respectively, indicating potent serum distribution via albumins.
\end{abstract}

\section{Introduction}

The potential use of zinc complexes as antidiabetic insulin mimetics [1], antimicrobial [2], and anticancer agents [3] have garnered a renewed interest in such complexes among other applications, such as serving as tumor photo sensitizers [4], radioprotective agents [5], and antidandruff agents (Zn pyrithione-ZPT) [6]. Our interest in sulfa drug moieties has been fueled by the fact that they possess a wide range of pharmaceutical applications [7]. Of particular interest are 1,2,4-triazine derivatives because they have been reported to possess many biological activities such as kinase inhibition [8], antihypertensivity [9], antimicrobial [10], anticancer [11], anti-HIV [12, 13], and anti-inflammatory activities [8].

Novel polyanionic sulfonated aromatic synthetic platinum chelates were preliminarily evaluated for their HIV-1 virucidal activity, due to the presence of sulfonated aromatic groups and metals in the most active members [14, 15]. Furthermore, we recently reported that rhenium tricarbonyl complexes of ferene and ferrozine have exhibited the potential to be used as biological imaging agents [16]. (Chemical structures of ferene and ferrozine are illustrated in Figure 1.) However, to the best of our knowledge, no reports exist of zinc complexes of sulfonated 1,2,4-triazine derivatives.

It is noteworthy that although zinc complexes bearing the 5,6-diphenyl-3, 2-pyridyl-1 2,4-triazine ligand were first synthesized more than a decade ago $[17,18]$, biological studies have been reported for only one such complex, albeit only recently [19]. Therefore, our goal has been to synthesize zinc complexes bearing sulfonated pyridyl triazine derivatives and to assess their interaction with biological targets.

Being the most abundant protein in blood, serum albumin maintains the colloid osmotic pressure, while playing a major role in transport and sustained release of many biomolecules such as steroids, fatty acids, and hormones. Serum albumin also serves as a carrier protein for drug molecules [20]. Small molecule interaction with serum 

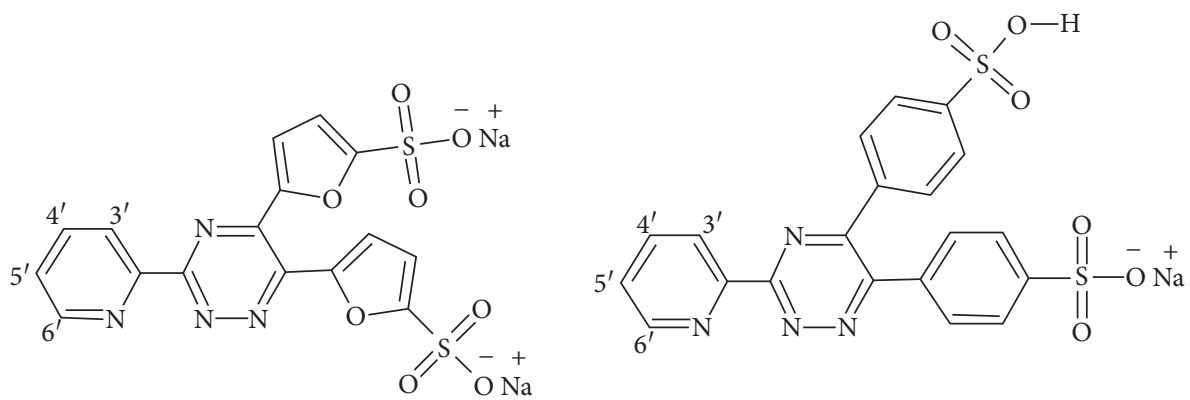

Figure 1: Chemical structures of 3-(2-pyridyl)-5,6-di(2-furyl)-1,2,4-triazine- $5^{\prime}, 5^{\prime \prime}$-disulfonic acid disodium salt (ferene: L1) (left) and 3-(2-pyridyl)-5,6-diphenyl-1,2,4-triazine- $4^{\prime}, 4^{\prime \prime}$-disulfonic acid sodium salt (ferrozine: L2) (right).

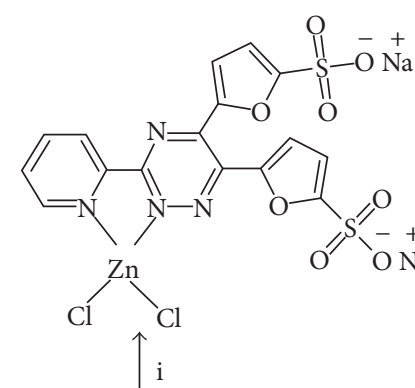

$\mathrm{i}$

$\mathrm{ZnCl}_{2}(\mathrm{~A})+\mathrm{L} 1(\mathrm{~B})$

$\mathrm{ZnCl}_{2}(\mathrm{~A})+\mathrm{L} 2(\mathrm{C})$

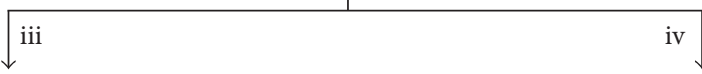

iv

ii<smiles></smiles>

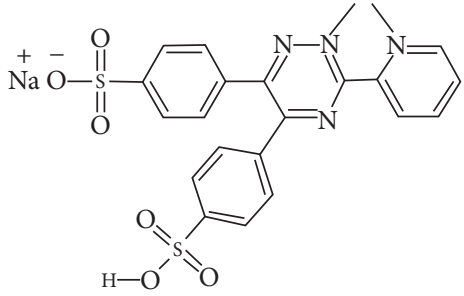

Conditions: (i) $\mathrm{A}: \mathrm{B}=1$, (ii) $\mathrm{A}: \mathrm{B}=1: 2$, (iii) $\mathrm{A}: \mathrm{C}=1: 1$, (iv) $\mathrm{A}: \mathrm{C}=1: 2$

Figure 2: Synthetic routes for the preparation $\mathrm{ML}_{1} \mathrm{Cl}_{2}$ (complex 1) (i), $\mathrm{M}(\mathrm{L} 1)_{2} \mathrm{Cl}_{2}$ (complex 2) (ii), $\mathrm{ML}_{2} \mathrm{Cl}_{2}$ (complex 3) (iii), and $\mathrm{M}(\mathrm{L} 2)_{2} \mathrm{Cl}_{2}$ (complex 4) (iv) complexes. An associated molecule of $\mathrm{ZnCl}_{2}$ in complex $\mathbf{1}$ and solvent molecules in complexes 1-4 have been omitted for clarity.

albumin is thus exploited in pharmaceutical research, where affinity to albumins is indicative of drugs with high serum distribution [21]. Through the interaction between bovine serum albumin (BSA), an analog of human serum albumin, and the novel compounds, we seek to investigate their pharmacokinetic associations.

Thus, we report here the synthesis and characterization of four novel metal complexes of the type $\mathrm{ML}_{n} \mathrm{Cl}_{2}$ (Figure 2) 
(where $\mathrm{M}=\mathrm{Zn}^{2+}, \mathrm{L}=3$-(2-pyridyl)-5,6-di(2-furyl)-1,2,4-triazine$5^{\prime}, 5^{\prime \prime}$-disulfonic acid disodium salt/3-(2-pyridyl)-5,6-diphenyl$1,2,4$-triazine- $4^{\prime}, 4^{\prime \prime}$-disulfonic acid sodium salt and $\left.n=1 / 2\right)$ and their BSA-binding studies.

\section{Experimental}

2.1. Materials and Methods. All chemicals (zinc chloride (3(2-pyridyl)-5,6-di(2-furyl)-1,2,4-triazine- $5^{\prime}, 5^{\prime \prime}$-disulfonic acid disodium salt (ferene/L1) and 3-(2-pyridyl)-5,6-diphenyl1,2,4-triazine- $4^{\prime}, 4^{\prime \prime}$-disulfonic acid sodium salt (ferrozine/L2)), methanol, diethyl ether, ethanol, bovine serum albumin (BSA), tris-HCl buffer (tris(hydroxymethyl)-aminomethane), sodium chloride $(\mathrm{NaCl})$, and analytical grade water) were obtained from Sigma-Aldrich. All the solvents and chemicals were of analytical grade and were used as received, without further purification.

2.2. NMR Measurements. ${ }^{1} \mathrm{H}$ NMR spectra were recorded in $\mathrm{D}_{2} \mathrm{O}$ on a Bruker $400 \mathrm{MHz}$ spectrometer. Peak positions are relative to tetramethylsilane (TMS) as reference. All NMR data were processed with TopSpin 3.2 and Mestre-C software.

2.3. Elemental Analysis. CHNS elemental analysis was performed by PerkinElmer 2400 Series II CHNS/O Elemental analyzer at Atlantic Microlab, USA.

2.4. Melting Point Determination. Melting points were manually determined in open capillaries.

2.5. UV-Visible Spectroscopy. Electronic spectra for ligand and metal complex were obtained on Spectro UV-Vis auto version 3.10, UV-2602 spectrophotometer. The spectral range was $200-800 \mathrm{~nm}$. Spectra were obtained in methanol with baseline correction. Spectral data were processed with UV WIN software.

2.6. FTIR Analysis. FTIR spectra were recorded on a Thermo Scientific NICOLET iS10 spectrophotometer. ATR spectra were obtained within the $4000-600 \mathrm{~cm}^{-1}$ spectral range. Spectral data were processed with OMNIC software.

2.6.1. Preparation of $\left[\mathrm{Zn}(\mathrm{L} 1) \mathrm{Cl}_{2}\right] \cdot 5 \mathrm{H}_{2} \mathrm{O} \cdot \mathrm{ZnCl}_{2}$ (1). A solution of ferene $(0.1 \mathrm{mmol}, 0.0494 \mathrm{~g})$ in methanol $\left(4.0 \mathrm{~cm}^{3}\right)$ was added to zinc chloride $(0.1 \mathrm{mmol}, 0.0140 \mathrm{~g})$ in methanol $\left(1.0 \mathrm{~cm}^{3}\right)$. Then, the resulting mixture was stirred for 3 hours at $60-70^{\circ} \mathrm{C}$ [1]. The yellow precipitate which was obtained was collected by filtration, washed with ethanol and diethyl ether, and dried. $\mathrm{C}_{16} \mathrm{H}_{8} \mathrm{Cl}_{2} \mathrm{~N}_{4} \mathrm{Na}_{2} \mathrm{O}_{8} \mathrm{~S}_{2} \mathrm{Zn} \cdot 5 \mathrm{H}_{2} \mathrm{O} \cdot \mathrm{ZnCl}_{2}$, yield $0.0517 \mathrm{~g}$, $78 \%$. Anal. calc. for $\mathrm{C}_{16} \mathrm{H}_{8} \mathrm{Cl}_{2} \mathrm{~N}_{4} \mathrm{Na}_{2} \mathrm{O}_{8} \mathrm{~S}_{2} \mathrm{Zn} \cdot 5 \mathrm{H}_{2} \mathrm{O} \cdot \mathrm{ZnCl}_{2}$ : C, 22.54; H, 1.92; N, 6.68; S, 7.64. Found: C, 22.13; H, 1.89; N, 6.57; S, 7.70\%; melting point: $>315^{\circ} \mathrm{C}$; UV-Vis $(\mathrm{MeoH})\left(\lambda_{\max }(\mathrm{nm})\right.$ $\left.\left(\varepsilon \mathrm{M}^{-1} \cdot \mathrm{cm}^{-1}\right)\right): 210,242,331,364$; FTIR (ATR) $\left(\mathrm{cm}^{-1}\right): 1504$ $(v(\mathrm{~N}=\mathrm{N})), 1582(v(\mathrm{C}=\mathrm{N})) ;{ }^{1} \mathrm{H}$ NMR $\left(\mathrm{D}_{2} \mathrm{O}, \delta \mathrm{ppm}\right) 8.87\left(\mathrm{~d}, \mathrm{H}_{6}\right)$, $8.79\left(\mathrm{~d}, \mathrm{H}_{3}\right), 8.28\left(\mathrm{t}, \mathrm{H}_{4}\right), 7.87\left(\mathrm{t}, \mathrm{H}_{5}\right), 7.09-7.46(\mathrm{~m}, 4 \mathrm{H}$, furyl $\mathrm{H})$.
2.6.2. Preparation of $\left[\mathrm{Zn}(\mathrm{L} 1)_{2} \mathrm{Cl}_{2}\right] \cdot 4 \mathrm{H}_{2} \mathrm{O} \cdot 2 \mathrm{CH}_{3} \mathrm{OH}$ (2). A solution of ferene $(0.2 \mathrm{mmol}, 0.0988 \mathrm{~g})$ in methanol $\left(4.0 \mathrm{~cm}^{3}\right)$ was added to zinc chloride $(0.1 \mathrm{mmol}, 0.0140 \mathrm{~g})$ in methanol $\left(1.0 \mathrm{~cm}^{3}\right)$ [2]. Then, the resulting mixture was stirred for 6 hours at $60-70^{\circ} \mathrm{C}$. The yellow precipitate which was obtained was collected by filtration, washed with ethanol and diethyl ether, and dried. $\mathrm{C}_{32} \mathrm{H}_{16} \mathrm{Cl}_{2} \mathrm{~N}_{8} \mathrm{Na}_{4} \mathrm{O}_{16} \mathrm{~S}_{4} \mathrm{Zn} \cdot 4 \mathrm{H}_{2} \mathrm{O} \cdot 2 \mathrm{CH}_{3} \mathrm{OH}$, yield $0.0689 \mathrm{~g}, 61 \%$ based on zinc chloride. Anal. calc. for $\mathrm{C}_{32} \mathrm{H}_{16} \mathrm{Cl}_{2} \mathrm{~N}_{8} \mathrm{Na}_{4} \mathrm{O}_{16} \mathrm{~S}_{4} \mathrm{Zn} \cdot 4 \mathrm{H}_{2} \mathrm{O} \cdot 2 \mathrm{CH}_{3} \mathrm{OH}: \mathrm{C}, 32.38 ; \mathrm{H}, 2.56 ; \mathrm{N}$, 9.26; S, 10.57. Found: C, 32.5; H, 2.67; N, 9.63; S, 10.83\%; melting point: $>315^{\circ} \mathrm{C}$; UV-Vis $(\mathrm{MeoH})\left(\lambda_{\max }(\mathrm{nm})\left(\varepsilon \mathrm{M}^{-1} \cdot \mathrm{cm}^{-1}\right)\right): 209$, 244, 337, 370; FTIR (ATR) $\left(\mathrm{cm}^{-1}\right): 1511 \quad(v(\mathrm{~N}=\mathrm{N})), 1586$ $(v(\mathrm{C}=\mathrm{N})) ;{ }^{1} \mathrm{H} \operatorname{NMR}\left(\mathrm{D}_{2} \mathrm{O}, \delta \mathrm{ppm}\right) 8.86\left(\mathrm{~d}, \mathrm{H}_{6}\right), 8.76\left(\mathrm{~d}, \mathrm{H}_{3}\right)$, $8.27\left(\mathrm{t}, \mathrm{H}_{4}\right), 7.84\left(\mathrm{t}, \mathrm{H}_{5}\right), 7.15-7.41(\mathrm{~m}, 8 \mathrm{H}$, furyl $\mathrm{H})$.

2.6.3. Preparation of $\left[\mathrm{Zn}(\mathrm{L} 2) \mathrm{Cl}_{2}\right] \cdot 3 \mathrm{H}_{2} \mathrm{O} \cdot \mathrm{CH}_{3} \mathrm{OH}$ (3). A solution of ferrozine $(0.1 \mathrm{mmol}, 0.0492 \mathrm{~g})$ in methanol $\left(4.0 \mathrm{~cm}^{3}\right)$ was added to zinc chloride $(0.1 \mathrm{mmol}, 0.0140 \mathrm{~g})$ in methanol $\left(1.0 \mathrm{~cm}^{3}\right)$ [3]. Then, the resulting mixture was stirred for 3 hours at $60-70^{\circ} \mathrm{C}$. The light yellow precipitate which was obtained was collected by filtration, washed with ethanol and diethyl ether, and dried. $\mathrm{C}_{20} \mathrm{H}_{13} \mathrm{Cl}_{2} \mathrm{~N}_{4} \mathrm{NaO}_{6} \mathrm{~S}_{2} \mathrm{Zn} \cdot 3 \mathrm{H}_{2} \mathrm{O} \cdot \mathrm{CH}_{3} \mathrm{OH}$, yield $0.0433 \mathrm{~g}, 69 \%$ based on zinc chloride. Anal. calc. for $\mathrm{C}_{20} \mathrm{H}_{13} \mathrm{Cl}_{2} \mathrm{~N}_{4} \mathrm{NaO}_{6} \mathrm{~S}_{2} \mathrm{Zn} \cdot 3 \mathrm{H}_{2} \mathrm{O} \cdot \mathrm{CH}_{3} \mathrm{OH}: \mathrm{C}, 35.28 ; \mathrm{H}, 4.24 ; \mathrm{N}$, 7.84; S, 8.97. Found: C, 35.27; H, 4.36; N, 7.89; S, 9.13\%; melting point: $>315^{\circ} \mathrm{C}$; UV-Vis $(\mathrm{MeoH})\left(\lambda_{\max }(\mathrm{nm})\left(\varepsilon \mathrm{M}^{-1} \cdot \mathrm{cm}^{-1}\right)\right): 208$, 240, 291, 323; FTIR (ATR) $\left(\mathrm{cm}^{-1}\right): 1497(v(\mathrm{~N}=\mathrm{N})), 1599$ $(v(\mathrm{C}=\mathrm{N})) ;{ }^{1} \mathrm{H} \operatorname{NMR}\left(\mathrm{D}_{2} \mathrm{O}, \delta \mathrm{ppm}\right) 8.86\left(\mathrm{~d}, \mathrm{H}_{6}\right), 8.76\left(\mathrm{~d}, \mathrm{H}_{3}\right)$, $8.27\left(\mathrm{t}, \mathrm{H}_{4}\right), 7.84\left(\mathrm{t}, \mathrm{H}_{5}\right), 7.46-8.28(\mathrm{~m}, 8 \mathrm{H}$, phenyl $\mathrm{H})$.

2.6.4. Preparation of $\left[\mathrm{Zn}(\mathrm{L} 2)_{2} \mathrm{Cl}_{2}\right] \cdot 5 \mathrm{H}_{2} \mathrm{O} \cdot \mathrm{CH}_{3} \mathrm{OH}$ (4). A solution of ferrozine $(0.2 \mathrm{mmol}, 0.0984 \mathrm{~g})$ in methanol $\left(4.0 \mathrm{~cm}^{3}\right)$ was added to zinc chloride $(0.1 \mathrm{mmol}, 0.0140 \mathrm{~g})$ in methanol $\left(1.0 \mathrm{~cm}^{3}\right)$ [4]. Then, the resulting mixture was stirred for 6 hours at $60-70^{\circ} \mathrm{C}$. The light yellow precipitate which was obtained was collected by filtration, washed with ethanol and diethyl ether, and dried. $\mathrm{C}_{41} \mathrm{H}_{40} \mathrm{Cl}_{2} \mathrm{~N}_{8} \mathrm{Na}_{2} \mathrm{O}_{18} \mathrm{~S}_{4} \mathrm{Zn} \cdot 5 \mathrm{H}_{2} \mathrm{O} \cdot \mathrm{CH}_{3} \mathrm{OH}$, yield: $0.0579 \mathrm{~g}, 52 \%$ based on zinc chloride. Anal. calc. for $\mathrm{C}_{41} \mathrm{H}_{40} \mathrm{Cl}_{2} \mathrm{~N}_{8} \mathrm{Na}_{2} \mathrm{O}_{18} \mathrm{~S}_{4} \mathrm{Zn} \cdot 5 \mathrm{H}_{2} \mathrm{O} \cdot \mathrm{CH}_{3} \mathrm{OH}: \mathrm{C}, 39.59 ; \mathrm{H}, 3.24 ; \mathrm{N}$, 9.01; S, 10.32. Found: C, 38.93; H, 3.04; N, 8.84; S, 10.67\%; melting point: $>315^{\circ} \mathrm{C}$; UV-Vis $(\mathrm{MeoH})\left(\lambda_{\max }(\mathrm{nm})\right.$ $\left.\left(\varepsilon \mathrm{M}^{-1} \cdot \mathrm{cm}^{-1}\right)\right): 216,242,298$, 336; FTIR (ATR) $\left(\mathrm{cm}^{-1}\right): 1498$ $(v(\mathrm{~N}=\mathrm{N})), 1596(v(\mathrm{C}=\mathrm{N})) ;{ }^{1} \mathrm{H}$ NMR $\left(\mathrm{D}_{2} \mathrm{O}, \delta \mathrm{ppm}\right) 9.05$ $\left(\mathrm{d}, \mathrm{H}_{6}\right), 8.99\left(\mathrm{~d}, \mathrm{H}_{3}\right), 8.67\left(\mathrm{t}, \mathrm{H}_{4}\right), 8.67\left(\mathrm{t}, \mathrm{H}_{5}\right), 7.50-8.31$ (m, $16 \mathrm{H}$, phenyl $\mathrm{H}$ ).

2.7. BSA-Binding Assay. A $6 \mu \mathrm{M}$ BSA solution was prepared in a buffer containing $5 \mathrm{mM}$ tris- $\mathrm{HCl} / 50 \mathrm{mM} \mathrm{NaCl}$ by continuous stirring for $1 \mathrm{hr}$ at room temperature. A $1 \times 10^{-3} \mathrm{M}$ stock solution of complexes and ligand was prepared in distilled water.

Absorption titration was carried out by keeping BSA concentration constant $(6 \mu \mathrm{M})$ and varying the concentrations of the complexes and ligand $(010 \mu \mathrm{M})$. After $10 \mathrm{~min}$ incubation at room temperature, absorbance was measured for each solution in the range of $250-300 \mathrm{~nm}$ wavelengths, and $\lambda_{\max }$ was recorded at $280 \mathrm{~nm}$. Then, the change of $\lambda_{\max }$ 
Table 1: Comparison of UV-Vis data of ferene, ferrozine, and complexes 1-4.

\begin{tabular}{lcccccc}
\hline$\lambda_{\mathrm{Zn}^{2+}}(\mathrm{nm})$ & $\lambda_{\text {ferene }}(\mathrm{nm})$ & $\lambda_{\text {complex 1 }}(\mathrm{nm})$ & $\lambda_{\text {complex 2 }}(\mathrm{nm})$ & $\lambda_{\text {ferrozine }}(\mathrm{nm})$ & $\lambda_{\text {complex 3 }}(\mathrm{nm})$ & $\lambda_{\text {complex 4 }}(\mathrm{nm})$ \\
\hline 207 & 209 & 210 & 209 & 211 & 208 & 246 \\
222 & 243 & 242 & 244 & 236 & 285 & 291 \\
- & 306 & 331 & 337 & 370 & 310 & 323 \\
- & 339 & 364 & 370 & 298 \\
\hline
\end{tabular}

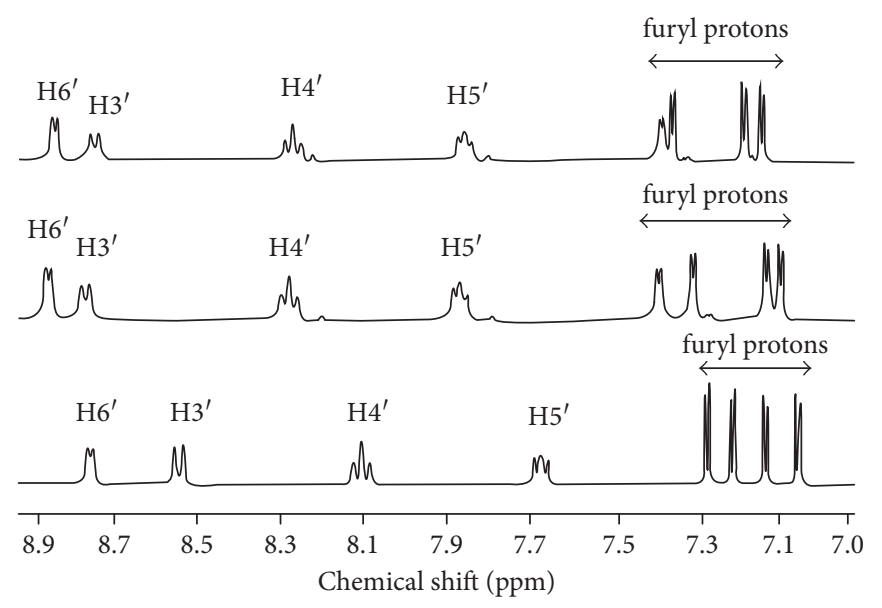

Figure 3: ${ }^{1} \mathrm{H}$ NMR spectrum of ferene (bottom) and complexes 1 (middle) and 2 (top).

was recorded for each solution. All absorbance measurements were triplicated and corrected for background absorbance by the compounds. The plot of $1 /\left(A-A_{0}\right)$ (where $A_{0}$ is the initial absorbance of the free BSA at $280 \mathrm{~nm}$ and $A$ is the absorbance of BSA in the presence of different concentrations of the complex) versus $1 /$ [complex] is a linear curve, and the binding constant $\left(K_{\mathrm{b}}\right)$ can be obtained from the ratio of the intercept to slope [19].

\section{Results and Discussion}

3.1. Synthesis. In order to synthesize the metal complexes, zinc chloride and the relevant ligands in $1: 1$ and $1: 2$ ratios were used (Figure 2).

3.2. UV-Visible Spectroscopy. UV-visible spectra of ligands and complexes $\mathbf{1 - 4}$ recorded in methanol showed significant differences between the absorption peaks of ligands and their complexes (Table 1, Figures S1 and S2, Supporting Information). Since both ligands bear conjugated systems, $\pi-\pi^{*}$ transition is possible. In all four complexes, the wavelengths have shifted towards the longer wavelength range (bathochromic shift) because of changes in the conjugated electron system due to formation of metal ligand bonds. These observations are in agreement with previously reported zinc pyridyl triazine derivatives [18] and copper pyridyl triazine derivatives [22], upon coordination of ligand to metal.

3.3. ${ }^{1} \mathrm{H}$ NMR Analysis. Complexes 1-4 were characterized using ${ }^{1} \mathrm{H}$ NMR spectroscopy in $\mathrm{D}_{2} \mathrm{O}$. All the peaks were

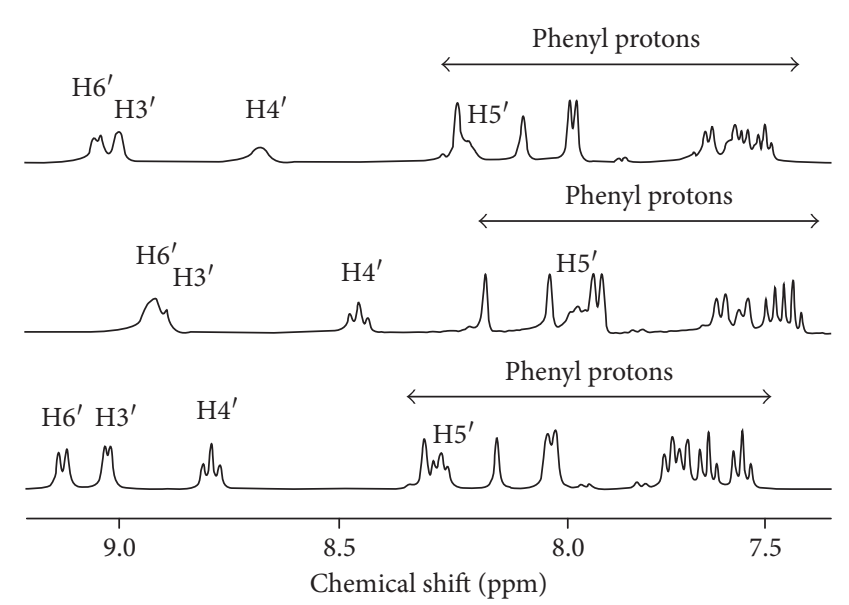

FIgURE 4: ${ }^{1} \mathrm{H}$ NMR spectrum of ferrozine (bottom) and complexes 3 (middle) and 4 (top).

assigned in comparison with related structures of both ligands (Figures 3 and 4).

The splitting pattern of the free ferene ligand can be observed for complexes $\mathbf{1}$ and $\mathbf{2}$. However, due to the donation of electrons from the nitrogen in pyridine and triazine rings to the metal, the electron density of the ferene ligand is reduced, and thus protons of the metal complex should appear more downfield than the ferene ligand. Furthermore, the downfield shift, which will hence be denoted as $\Delta \delta$, of the $\mathrm{H}_{6}$ signal is expected to be higher than that of other protons because it is closer to the pyridine N. In uncoordinated ferene ligand (L1), the pyridyl $\mathrm{H}_{6}$ signal (8.74 ppm, Table 2) is its most downfield doublet consistent 
TABle 2: Selected ${ }^{1} \mathrm{H}$ NMR chemical shifts (ppm) of ferene, ferrozine, and complexes $\mathbf{1 - 4}$.

\begin{tabular}{lcccc}
\hline Proton no. & $\mathrm{H}_{6}(\mathrm{~d})$ & $\mathrm{H}_{5}(\mathrm{t})$ & $\mathrm{H}_{4}(\mathrm{t})$ & $\mathrm{H}_{3}(\mathrm{~d})$ \\
\hline Ferene & 8.74 & 7.67 & 8.10 & 8.54 \\
Ferrozine & 9.15 & 8.27 & 8.81 & 9.05 \\
Complex 1 & 8.87 & 7.87 & 8.28 & 8.79 \\
Complex 2 & 8.86 & 7.84 & 8.27 & 8.76 \\
Complex 3 & 8.92 & 7.98 & 8.47 & 8.89 \\
Complex 4 & 9.05 & 8.21 & 8.67 & 8.99 \\
$\Delta \delta(\mathrm{ppm})$ of complex 1 & $(+) 0.13$ & $(+) 0.20$ & $(+) 0.18$ & $(+) 0.25$ \\
$\Delta \delta(\mathrm{ppm})$ of complex 2 & $(+) 0.12$ & $(+) 0.17$ & $(+) 0.17$ & $(+) 0.22$ \\
$\Delta \delta(\mathrm{ppm})$ of complex 3 & $(-) 0.23$ & $(-) 0.29$ & $(-) 0.34$ & $(-) 0.16$ \\
$\Delta \delta(\mathrm{ppm})$ of complex 4 & $(-) 0.10$ & $(-) 0.06$ & $(-) 0.14$ & $(-) 0.06$ \\
\hline
\end{tabular}

with its close proximity to the pyridyl nitrogen atom. In a spectrum of complex $\mathbf{1}$, the $\mathrm{H}_{6}$ signal appears further downfield (8.87 ppm, Figure 3) confirming metal-pyridine $\mathrm{N}$ bond formation. However, the observed change in shift of $\mathrm{H}_{6}$ was small in both $1(\Delta \delta ;+0.13 \mathrm{ppm}$ at $8.87 \mathrm{ppm})$ and 2 $((\Delta \delta ;+0.12 \mathrm{ppm}$ at $8.86 \mathrm{ppm})$ in comparison with the change in shift observed for the $\mathrm{H}_{3}$ proton $(8.79 \mathrm{ppm}$ and $8.76 \mathrm{ppm})$, which had the highest change in downfield shift $((\Delta \delta ;+0.25$ and $+0.22 \mathrm{ppm}$, resp.). The four doublets due to furyl ring protons (7.00-7.34 ppm range) also appear more downfield (7.15-7.45 ppm) upon metal bonding. Higher downfield shifts were observed for $\mathrm{H}_{3}$ versus $\mathrm{H}_{6}$ in ${ }^{1} \mathrm{H}$ NMR spectra of $\mathrm{Zn}$ (dppt) $\mathrm{Cl}_{2} \cdot 0 \cdot 5 \mathrm{H}_{2} \mathrm{O}$ and $\mathrm{Zn}(\mathrm{dppt})_{2} \mathrm{Cl}_{2} \cdot 2 \mathrm{H}_{2} \mathrm{O}$ (dppt $=5,6$ diphenyl-3(2-pyridyl)-1,2,4- triazine) reported previously [18].

Although we expected similar observations for spectra of complexes 3 and $\mathbf{4}$, unusual upfield shifts of the peaks attributed to $\mathrm{H}_{6}$ (8.92 and $\left.9.05 \mathrm{ppm}\right), \mathrm{H}_{5}$ (7.98 and $\left.8.21 \mathrm{ppm}\right), \mathrm{H}_{4}$ (8.47 and $8.67 \mathrm{ppm}$ ), and $\mathrm{H}_{3}$ (8.89 and $8.99 \mathrm{ppm}$ ) (Figure 4) were observed in complexes 3 and 4 , respectively, in comparison with that of the uncoordinated ferrozine ligand $\left(\mathrm{H}_{6}: 9.15 \mathrm{ppm}, \mathrm{H}_{5}: 8.27 \mathrm{ppm}, \mathrm{H}_{4}: 8.81 \mathrm{ppm}\right.$, and $\mathrm{H}_{3}$ : $9.05 \mathrm{ppm})$. We attribute the observed upfield shift to possible $\pi$ stacking of phenyl rings. Upfield shifts due to $\pi$ stacking have been reported in previous studies on $\mathrm{Zn}(\mathrm{II})$ with mono- and dianionic pyrrole-2-imine complexes and zinc azadipyrromethene [23]. Although the ${ }^{1} \mathrm{H}$ NMR spectrum of ferrozine/L2 is comparatively more complicated due to the protons of the two phenyl rings, the pyridyl ring protons can be easily distinguished (Figure 4). Upfield shifts observed in complexes $\mathbf{3}$ and $\mathbf{4}$ were not observed in complexes $\mathbf{1}$ and $\mathbf{2}$, which had furyl rings (Figure 3).

3.4. FTIR Analysis. Literature data have been used where relevant to get assignment of ligands [18]. The stretching frequency $(v)$ of the $\mathrm{N}=\mathrm{N}$ bond in the triazine ring and $\mathrm{C}=\mathrm{N}$ bond in the pyridine ring serves as important indicators of the formation of new metal ligand bonds [18]. In all four complexes, $v_{\mathrm{N}=\mathrm{N}}$ and $v_{\mathrm{C}=\mathrm{N}}$ have shifted to lower frequencies (Table 3) due to the formation of new metal ligand bonds which in turn lowers the strength of the $\mathrm{N}=\mathrm{N}$ and $\mathrm{C}=\mathrm{N}$ bonds. This observation allowed us to confirm that the complex was formed via the donation of a lone pair of
TABLE 3: FTIR data of complexes 1-4.

\begin{tabular}{lcc}
\hline Ligand/complex & $\nu_{\mathrm{C}=\mathrm{N}}\left(\mathrm{cm}^{-1}\right)$ & $\nu_{\mathrm{N}=\mathrm{N}}\left(\mathrm{cm}^{-1}\right)$ \\
\hline Ferene & 1590 & 1510 \\
Complex 1 & 1582 & 1504 \\
Complex 2 & 1586 & 1511 \\
Ferrozine & 1608 & 1502 \\
Complex 3 & 1599 & 1497 \\
Complex 4 & 1596 & 1498 \\
\hline
\end{tabular}

electrons each, from the triazine ring and from the pyridine ring, to zinc. For example, upon formation of complex 1, $\nu_{\mathrm{C}=\mathrm{N}}\left(1590 \mathrm{~cm}^{-1}\right)$ and $\nu_{\mathrm{N}=\mathrm{N}}\left(1510 \mathrm{~cm}^{-1}\right)$ appear at $1582 \mathrm{~cm}^{-1}$ and $1504 \mathrm{~cm}^{-1}$ (Table 3), respectively, due to the change in chemical environment. FTIR spectra show broad peaks at around $3400 \mathrm{~cm}^{-1}$ region due to $\mathrm{OH}$ vibration.

3.5. Elemental Analysis. Empirical formulas related to experimental values of the complexes (Experimental) give the exact molecular formulas and experimental values are closer to the expected values. Some deviate from the theoretical values due to the residual solvent (methanol) and water molecules.

Elemental analysis data suggest that complex $\mathbf{1}$ exists as $\left[\mathrm{Zn}(\mathrm{L} 1) \mathrm{Cl}_{2}\right] \cdot 5 \mathrm{H}_{2} \mathrm{O} \cdot \mathrm{ZnCl}_{2}$. The experimental data obtained from elemental analysis show a significant decrease in the carbon percentage of this complex than expected without the extra zinc ion, prompting us to include an associated zinc chloride molecule in $\mathbf{1}$. However, the exact binding mode or type of the interaction of this extra $\mathrm{ZnCl}_{2}$ molecule with ferene ligand cannot be explained with the obtained data. Complexes 2-4 have no such discrepancy, and the molecular formula were confirmed from elemental analysis to be $\left[\mathrm{Zn}(\mathrm{L} 1)_{2} \mathrm{Cl}_{2}\right] \cdot 4 \mathrm{H}_{2} \mathrm{O} \cdot 2 \mathrm{CH}_{3} \mathrm{OH}, \quad\left[\mathrm{Zn}(\mathrm{L} 2) \mathrm{Cl}_{2}\right] \cdot 3 \mathrm{H}_{2} \mathrm{O} \cdot \mathrm{CH}_{3} \mathrm{OH}$, and $\left[\mathrm{Zn}(\mathrm{L} 2)_{2} \mathrm{Cl}_{2}\right] \cdot 5 \mathrm{H}_{2} \mathrm{O} \cdot \mathrm{CH}_{3} \mathrm{OH}$, respectively.

3.6. BSA-Binding Assay. Anjomshoa and coworkers have previously investigated bovine serum albumin- (BSA-) binding properties of $\mathrm{Zn}(\mathrm{dppt})_{2} \mathrm{Cl}_{2} \cdot 2 \mathrm{H}_{2} \mathrm{O} \quad(\mathrm{dppt}=5$,6diphenyl-3,2-pyridyl-1 2,4-triazine) [19], which required an organic solvent such as dimethyl sulfoxide to be added to increase solubility. However, complexes 1-4 reported in this study are highly soluble in water which makes them compatible with biological systems.

Absorbance measurements at UV range are useful to identify the conformational changes in proteins. BSA has a maximum absorbance peak at $280 \mathrm{~nm}$. Analyzing the absorbance spectra of BSA upon addition of ferene, complex 1, and complex 2 (Figure 5) clearly shows that the peak intensity at $280 \mathrm{~nm}$ increases upon addition of the compounds, indicating association with BSA causes a change in the polarity of the microenvironment of tryptophan and tyrosine residues in a concentration dependent manner.

With increasing concentrations of ferene ligand and complexes $\mathbf{1}$ and $\mathbf{2}$, the maximum absorbance was increased. Using the graph of $1 /\left(A-A_{0}\right)$ against $1 /[\mathrm{C}]$, binding constants were calculated (Figure 6) as $3.09 \times 10^{4} \mathrm{M}^{-1}$, 

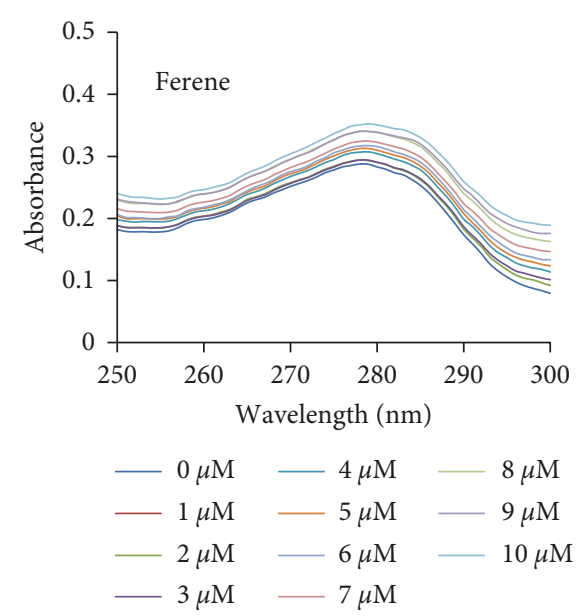
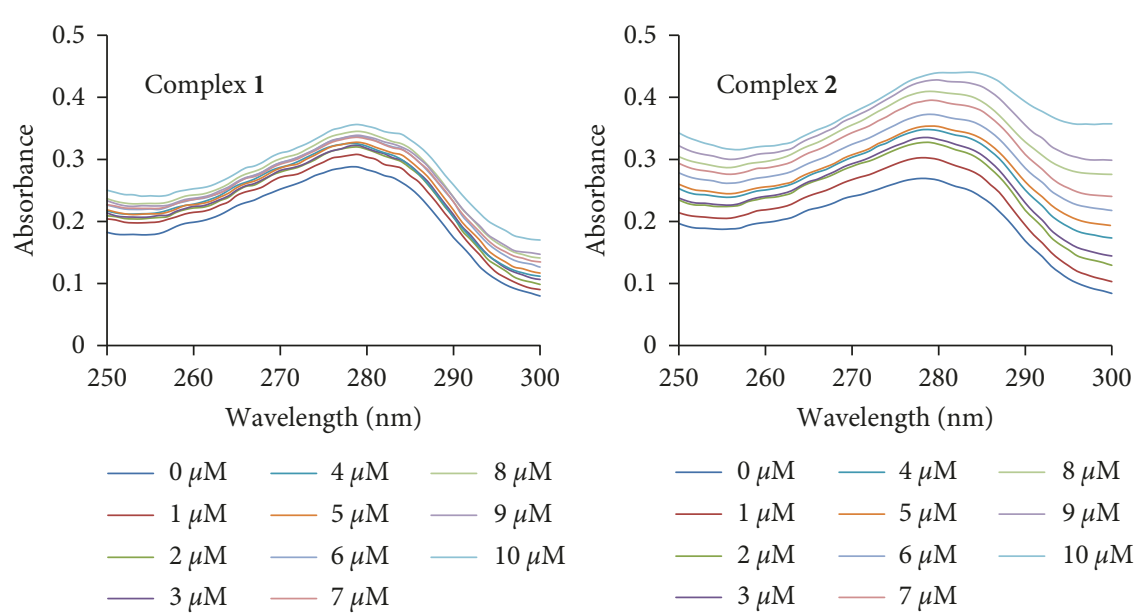

Figure 5: Absorbance spectra of BSA in the presence of different concentrations of ferene, complex 1, and complex 2.

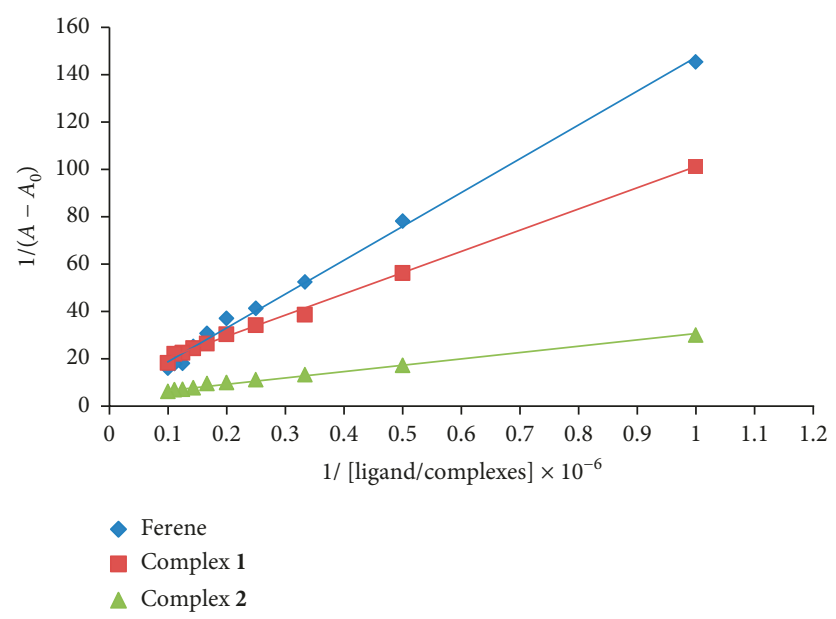

FiguRe 6: The graph of $1 /\left(A-A_{0}\right)$ versus $1 /$ [ligand/complexes] for ferene ligand $\left(R^{2}=0.9955\right)$, complex $1\left(R^{2}=0.9951\right)$, and complex 2 $\left(R^{2}=0.9955\right)$.

$12.30 \times 10^{4} \mathrm{M}^{-1}$, and $16.84 \times 10^{4} \mathrm{M}^{-1}$ for ferene, complex $\mathbf{1}$, and complex 2 , respectively. These values are within the range of $10^{4}-10^{6} \mathrm{M}^{-1}$ as expected from a good BSA carrier activity in vivo [19]. Such changes upon BSA addition were not observed in ferrozine and complexes 3 and 4 .

\section{Conclusions}

In this study, we have described the synthesis and characterization of four novel zinc complexes by spectroscopic methods. According to the UV-Vis spectra, a bathochromic shift has been observed for all four complexes. FTIR data provide evidence that $\mathrm{Zn}-\mathrm{N}$ bonds are formed via $\mathrm{N}$ atoms of the triazine and pyridine rings. Accordingly, the stretching frequency of $\mathrm{N}=\mathrm{N}$ and $\mathrm{C}=\mathrm{N}$ bonds of all four complexes have shifted to the low frequency range in comparison with the free ligands. Elemental analysis was used to determine the empirical formula of complexes 1-4.

It is our belief that the scaffolds reported herein may provide a novel platform for drug designing. We have demonstrated that such systems possess high affinity to serum albumin, indicating their potential to be distributed in serum [24]. Sulfonated groups have aided to increase water solubility of the complexes, where aqueous solubility predicted by ChemAxon (https://disco.chemaxon.com) have also supported that the new complexes are soluble in water under biologically relevant $\mathrm{pH}$ ranges (data not shown). In vivo testing is warranted to explore the implications of such properties on cellular metabolism to delineate the function of the novel triazine complexes in biological systems.

\section{Conflicts of Interest}

The authors declare that they have no conflicts of interest regarding the publication of this paper.

\section{Acknowledgments}

Financial assistance by Grant no. ASP/01/RE/SCI/2015/19 of the University of Sri Jayewardenepura is gratefully acknowledged. The authors thank Professor Luigi Marzilli and Ms. Kokila Ranasinghe of Louisiana State University for 
obtaining NMR data and for useful discussions. Ms. Taniya Darshani is acknowledged for determination of melting points.

\section{Supplementary Materials}

Figure S1. UV-visible spectra of $\mathrm{ZnCl}_{2}$, ferene, and complexes 1 and 2. Figure S2. UV-visible spectra of $\mathrm{ZnCl}_{2}$, ferrozine, and complexes 3 and 4. (Supplementary Materials)

\section{References}

[1] S. Fujimoto, H. Yasui, and Y. Yoshikawa, "Development of a novel antidiabetic zinc complex with an organoselenium ligand at the lowest dosage in KK-A(y) mice," Journal of Inorganic Biochemistry, vol. 121, pp. 10-15, 2013.

[2] N. Poulter, M. Donaldson, G. Mulley et al., "Plasma deposited metal Schiff-base compounds as antimicrobials," New Journal of Chemistry, vol. 35, no. 7, pp. 1477-1484, 2011.

[3] S. Anbu, S. Kamalraj, B. Varghese, J. Muthumary, and M. Kandaswamy, "A series of oxyimine-based macrocyclic dinuclear zinc(II) complexes enhances phosphate ester hydrolysis, DNA binding, DNA hydrolysis, and lactate dehydrogenase inhibition and induces apoptosis," Inorganic Chemistry, vol. 51, no. 10, pp. 5580-5592, 2012.

[4] Q. Huang, Z. Pan, P. Wang, Z. Chen, X. Zhang, and H. Xu, "Zinc(II) and copper(II) complexes of $\beta$-substituted hydroxylporphyrins as tumor photosensitizers," Bioorganic and Medicinal Chemistry Letters, vol. 16, no. 11, pp. 30303033, 2006.

[5] S. Emami, S. J. Hosseinimehr, S. M. Taghdisi, and S. Akhlaghpoor, "Kojic acid and its manganese and zinc complexes as potential radioprotective agents," Bioorganic and Medicinal Chemistry Letters, vol. 17, no. 1, pp. 45-48, 2007.

[6] K. V. Thomas, "Determination of the antifouling agent zinc pyrithione in water samples by copper chelate formation and high-performance liquid chromatography-atmospheric pressure chemical ionisation mass spectrometry," Journal of Chromatography A, vol. 833, no. 1, pp. 105-109, 1999.

[7] M. Aly, A. Gobouri, S. A. Hafez, and H. Saad, "Synthesis, reactions, and biological activity of some triazine derivatives containing sulfa drug moieties," Russian Journal of Bioorganic Chemistry, vol. 41, no. 4, pp. 437-450, 2015.

[8] J. T. Hunt, T. Mitt, R. Borzilleri et al., "Discovery of the pyrrolo[2,1-f] $[1,2,4]$ triazine nucleus as a new kinase inhibitor template," Journal of Medicinal Chemistry, vol. 47, no. 16, pp. 4054-4059, 2004.

[9] F. Krauth, H.-M. Dahse, H.-H. Rüttinger, and P. Frohberg, "Synthesis and characterization of novel 1,2,4-triazine derivatives with antiproliferative activity," Bioorganic and $\mathrm{Me}$ dicinal Chemistry, vol. 18, no. 5, pp. 1816-1821, 2010.

[10] S. K. Pandey, A. Singh, and A. Singh, "Antimicrobial studies of some novel quinazolinones fused with [1,2,4]-triazole, $[1,2,4]$-triazine and $[1,2,4,5]$-tetrazine rings," European Journal of Medicinal Chemistry, vol. 44, no. 3, pp. 1188-1197, 2009.

[11] Z. El-Gendy, J. Morsy, H. Allimony, W. Ali, and R. AbdelRahman, "Synthesis of heterobicyclic nitrogen systems bearing the 1,2,4-triazine moiety as anti-HIV and anticancer drugs, Part III,” Die Pharmazie, vol. 56, no. 5, pp. 376-383, 2001.

[12] R. Abdel-Rahman, "Chemistry of uncondensed 1,2,4-triazines. Part IV. Synthesis and chemistry of bioactive 3-amino1,2,4-triazines and related compounds-an overview," Die Pharmazie, vol. 56, no. 4, pp. 275-286, 2001.
[13] Y.-Z. Xiong, F.-E. Chen, J. Balzarini, E. De Clercq, and C. Pannecouque, "Non-nucleoside HIV-1 reverse transcriptase inhibitors. Part 11: structural modulations of diaryltriazines with potent anti-HIV activity," European Journal of Medicinal Chemistry, vol. 43, no. 6, pp. 1230-1236, 2008.

[14] A. Vzorov, D. Bhattacharyya, L. Marzilli, and R. Compans, "Prevention of HIV-1 infection by platinum triazines," Antiviral Research, vol. 65, no. 2, pp. 57-67, 2005.

[15] V. Maheshwari, D. Bhattacharyya, F. R. Fronczek, P. A. Marzilli, and L. G. Marzilli, "Chemistry of HIV-1 virucidal Pt complexes having neglected bidentate $\mathrm{sp}^{2} \mathrm{~N}$-donor carrier ligands with linked triazine and pyridine rings. synthesis, NMR spectral features, structure, and reaction with guanosine," Inorganic Chemistry, vol. 45, no. 18, pp. 7182-7190, 2006.

[16] K. Ranasinghe, S. Handunnetti, I. C. Perera, and T. Perera, "Synthesis and characterization of novel rhenium (I) complexes towards potential biological imaging applications," Chemistry Central Journal, vol. 10, no. 1, p. 71, 2016.

[17] F. Marandi, A. A. Soudi, A. Morsali, and R. Kempe, "Zinc(II) and cadmium(II) complexes of the 3-(2-Pyridyl)-5,6diphenyl-1,2,4-triazine (PDPT) ligand, structural studies of [Zn (PDPT) 2Cl $\left.\left(\mathrm{ClO}_{4}\right)\right]$ and [Cd $\left.(\mathrm{PDPT})_{2}\left(\mathrm{NO}_{3}\right)\left(\mathrm{ClO}_{4}\right)\right]$," Zeitschrift für anorganische und allgemeine Chemie, vol. 631, no. 15, pp. 3070-3073, 2005.

[18] V. Béreau and J. Marrot, "Coordination studies of 5,6diphenyl-3-(2-pyridyl)-1,2,4-triazine towards $\mathrm{Zn}^{2+}$ cation. Synthesis and characterization by X-ray diffraction and spectroscopic methods," Comptes Rendus Chimie, vol. 8, no. 6-7, pp. 1087-1092, 2005.

[19] M. Anjomshoa, S.J. Fatemi, M. Torkzadeh-Mahani, and H. Hadadzadeh, "DNA-and BSA-binding studies and anticancer activity against human breast cancer cells (MCF-7) of the zinc (II) complex coordinated by 5,6-diphenyl-3-(2-pyridyl)-1,2,4triazine," Spectrochimica Acta Part A: Molecular and Biomolecular Spectroscopy, vol. 127, pp. 511-520, 2014.

[20] O. A. Chaves, V. A. da Silva, C. M. R. Sant'Anna et al., "Binding studies of lophirone B with bovine serum albumin (BSA): combination of spectroscopic and molecular docking techniques," Journal of Molecular Structure, vol. 1128, pp. 606-611, 2017.

[21] M. E. Salive, J. Cornoni-Huntley, C. L. Phillips et al., "Serum albumin in older persons: relationship with age and health status," Journal of Clinical Epidemiology, vol. 45, no. 3, pp. 213-221, 1992.

[22] B. Machura, A. Świtlicka, R. Kruszynski, J. Mroziński, J. Kłak, and J. Kusz, "Coordination studies of 5,6-diphenyl-3(2-pyridyl)-1,2,4-triazine towards $\mathrm{Cu}^{2+}$ cation. X-ray studies, spectroscopic characterization and DFT calculations," Polyhedron, vol. 27, no. 13, pp. 2959-2967, 2008.

[23] T. S. Teets, D. V. Partyka, J. B. Updegraff III, and T. G. Gray, "Homoleptic, four-coordinate azadipyrromethene complexes of $\mathrm{d}^{10}$ zinc and mercury," Inorganic Chemistry, vol. 47, no. 7, pp. 2338-2346, 2008.

[24] F. Kratz, "Albumin as a drug carrier: design of prodrugs, drug conjugates and nanoparticles," Journal of Controlled Release, vol. 132, no. 3, pp. 171-183, 2008. 

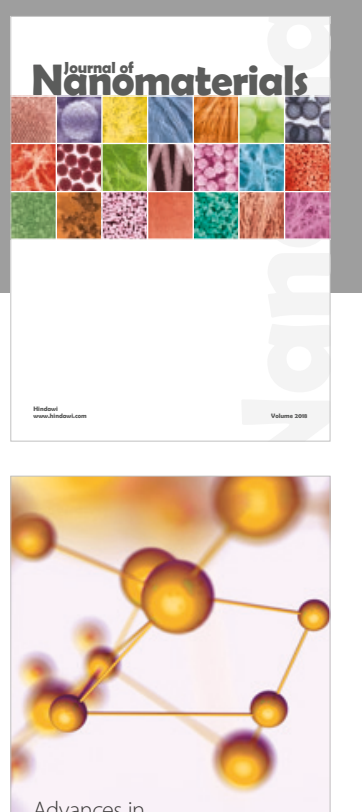

Physical Chemistry
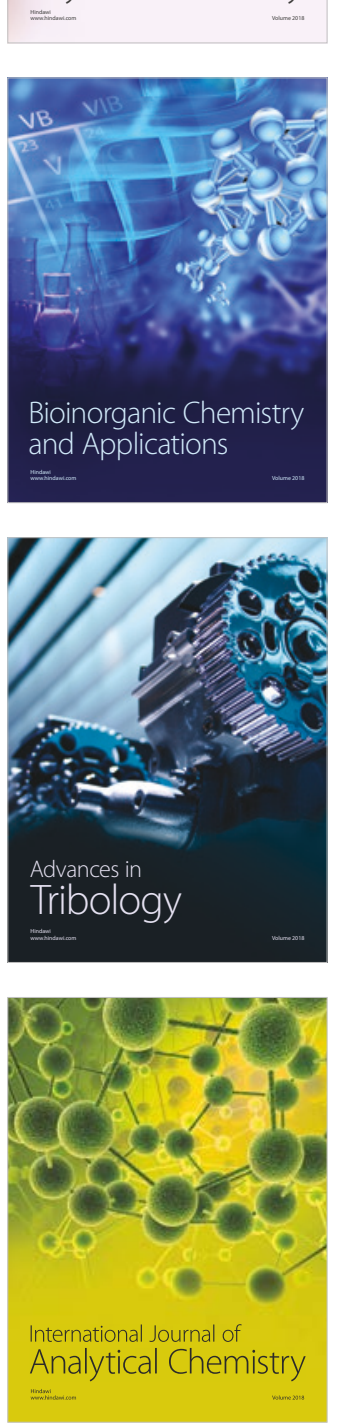

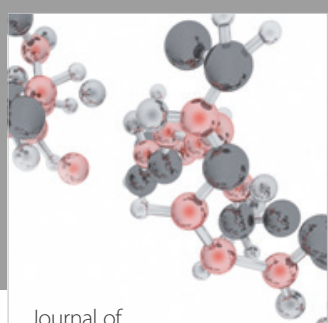

Analytical Methods

in Chemistry

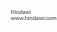

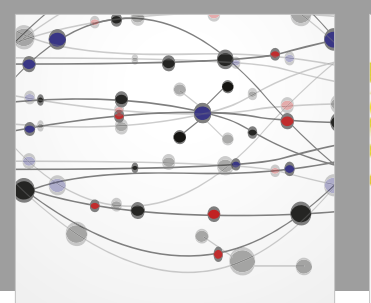

The Scientific World Journal

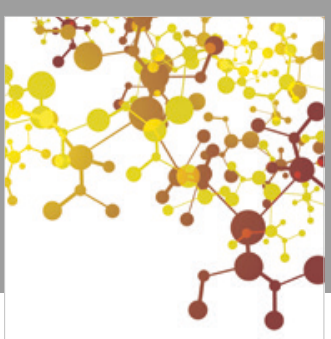

Journal of

Applied Chemistry
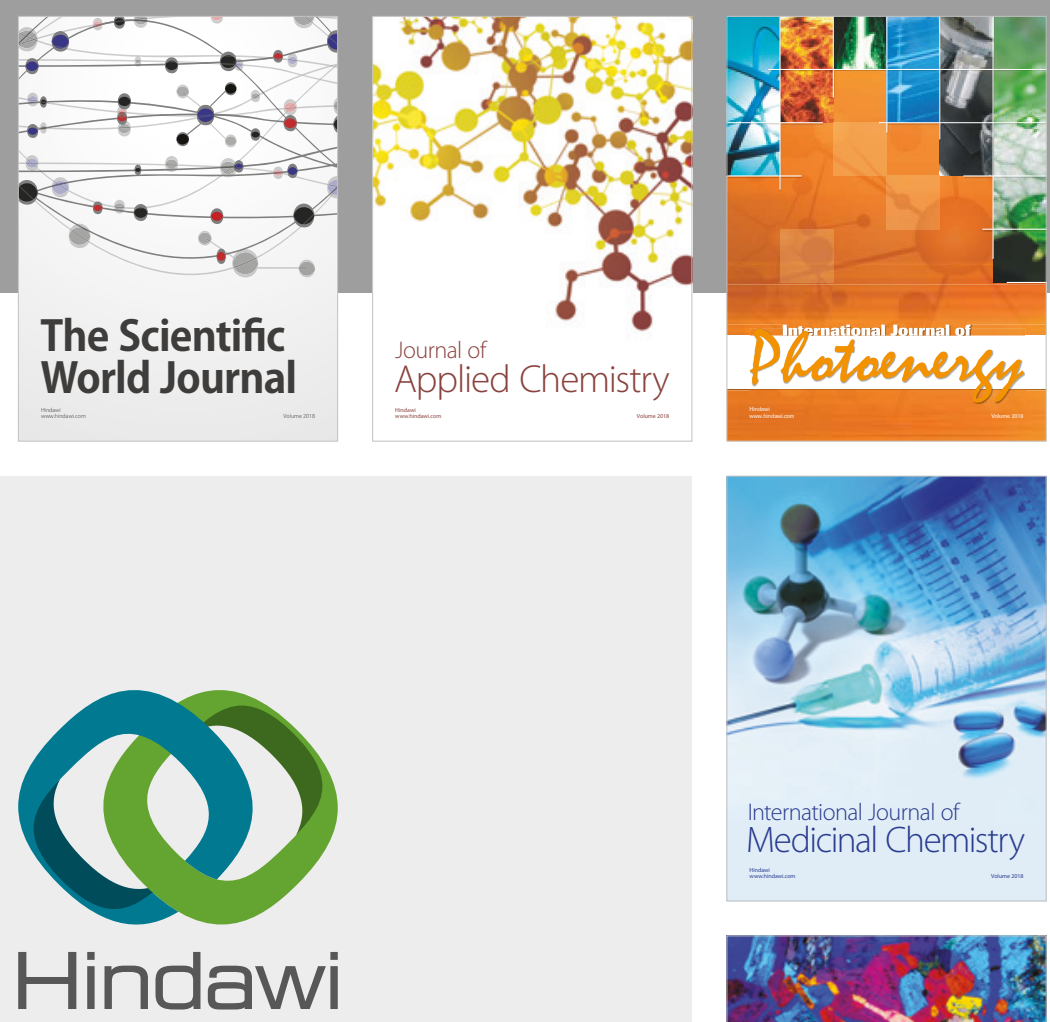

Submit your manuscripts at

www.hindawi.com
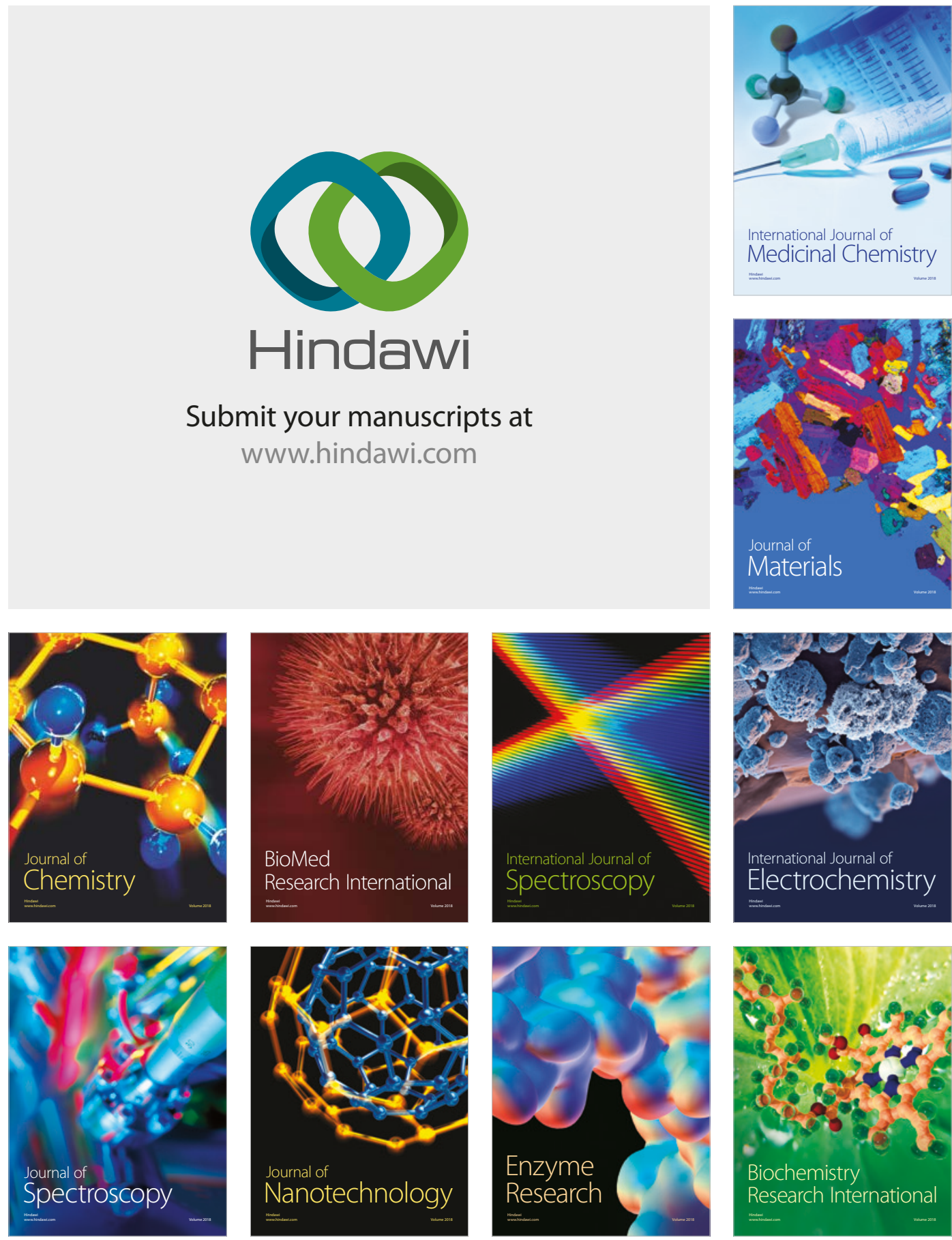
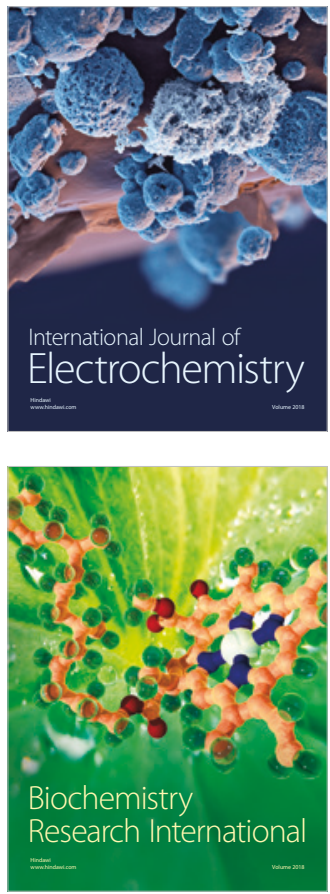